Document downloaded from:

http://hdl.handle.net/10251/67134

This paper must be cited as:

Mota Babiloni, A.; Navarro Esbri, J.; Penis, B.; Moles, F.; Verdú Martín, GJ. (2015).

Experimental evaluation of R448A as R404A lower-GWP alternative in refrigeration systems. Energy Conversion and Management. 105:756-762. doi:10.1016/j.enconman.2015.08.034.

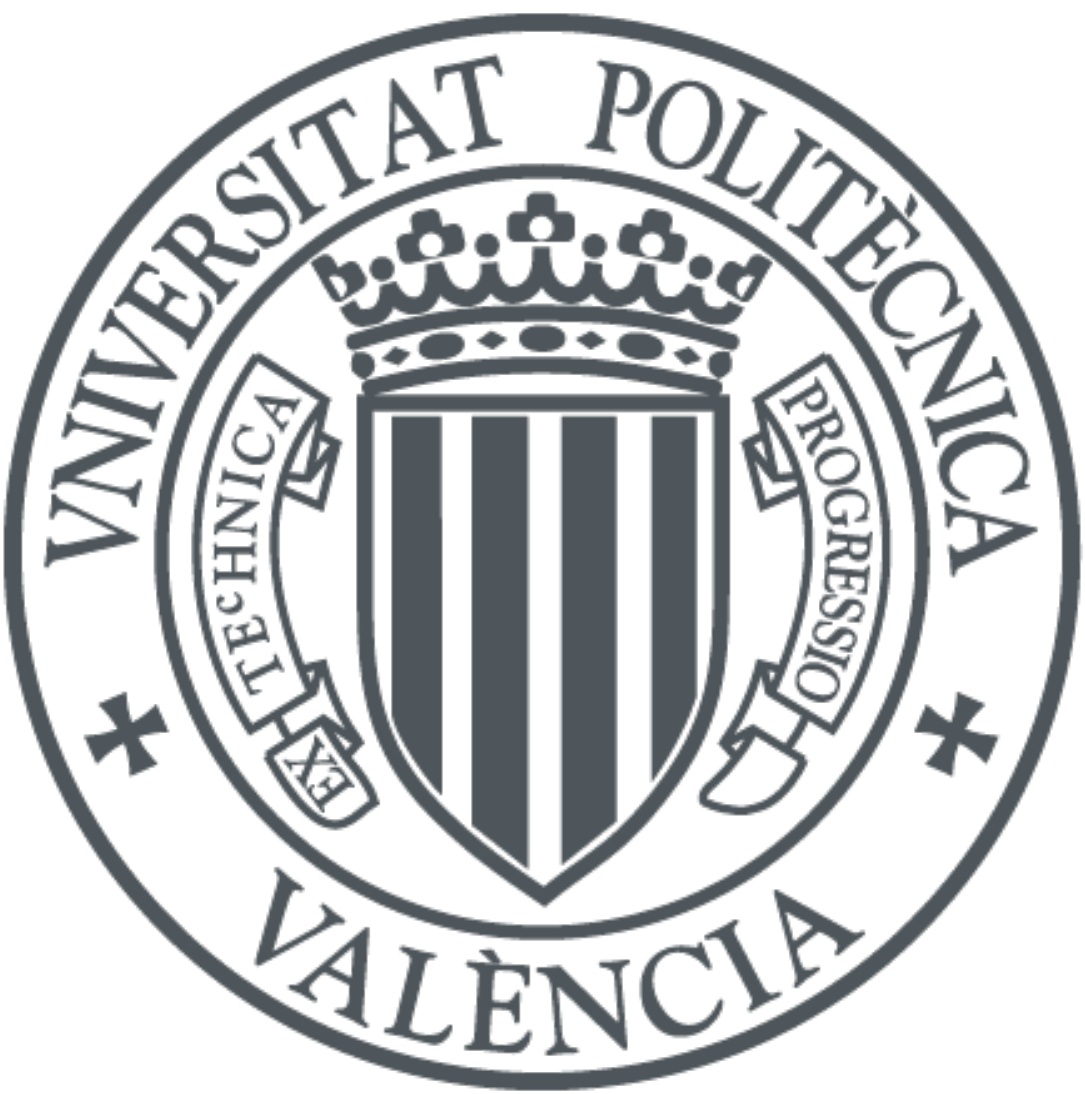

The final publication is available at

http://dx.doi.org/10.1016/j.enconman.2015.08.034

Copyright Elsevier

Additional Information 


\section{Evaluation of R448A and R450A as Low-GWP alternatives for R404A and R134a using a micro-fin tubes evaporator model}

Juan Manuel Mendoza-Miranda ${ }^{\mathrm{a}}$, Adrián Mota-Babiloni ${ }^{\mathrm{b}, c, 1}$, Joaquín Navarro-Esbrí ${ }^{\mathrm{c}}$

${ }^{a}$ Interdisciplinary Professional Unit of Engineering Campus Guanajuato. National Institute Polytechnic. Av. Mineral de Valenciana 200 Fracc. Industrial Puerto Interior, C.P. 36275, Silao de la Victoria, Guanajuato, Mexico.

${ }^{\mathrm{b}}$ Institute for Industrial, Radiophysical and Environmental Safety (ISIRYM), Camino de Vera s/n, Polytechnic University of Valencia, E46022, Valencia, Spain.

${ }^{\mathrm{c}}$ ISTENER Research Group, Department of Mechanical Engineering and Construction, Campus de Riu Sec s/n, University Jaume I, E12071, Castellón de la Plana, Spain.

\section{HIGHLIGHTS}

- Different correlations for flow boiling in microfin tubes are evaluated.

- Akhavan-Behabadi et al. correlation presents the best predictions.

- Min. and max. deviations occur with R134a and R450A, respectively.

- R450A and R134a evaporator performance almost the same.

- Due to high R448A glide, its evaporator performance is very different to R404A.

\section{Abstract}

When retrofitting new refrigerants in an existing vapour compression system, their adaptation to the heat exchangers is a major concern. R450A and R448A are commercial non-flammable mixtures with low GWP developed to replace the HFCs R134a and R404A, fluids with high GWP values. In this work the evaporator performance is evaluated through a shell-and-microfin tubes evaporator model using R450A, R448A, R134a and R404A. The accuracy of the model is first studied considering different recently developed micro-fin tubes correlations for flow boiling phenomena. The model is validated using experimental data from tests carried out in a fully monitored vapour compression plant at different refrigeration operating conditions. The main predicted operational parameters such as evaporating pressure, $\mathrm{UA}_{\mathrm{TP}}$, and cooling capacity, when compared with experimental data fits within $\pm 10 \%$ using Akhavan-Behabadi et al. correlation for flow boiling. Results show that R450A and R404A are the refrigerants in which the model fits better, even though R448A and $\mathrm{R} 134 \mathrm{a}$ predictions are also accurate.

\footnotetext{
${ }^{1}$ Corresponding Author:

Tel: +34 964387529; fax: +34964728106.

E-mail address: admoba@upv.es
} 
Keywords: R134a, R450A, R448A, R404A, flow boiling heat transfer correlations, evaporator model.

\section{Nomenclature}

\begin{tabular}{|c|c|}
\hline A & Heat transfer area $\left(\mathrm{m}^{2}\right)$ \\
\hline B o & Boiling number \\
\hline C & Constant \\
\hline$C_{p}$ & Specific heat capacity $\left(\mathrm{J} \mathrm{kg}^{-1} \mathrm{~K}^{-1}\right)$ \\
\hline$d$ & Diameter $(\mathrm{m})$ \\
\hline$e$ & Fin height (m) \\
\hline$g$ & Gravitational acceleration $\left(\mathrm{m} \mathrm{s}^{-2}\right)$ \\
\hline G & Mass velocity $\left(\mathrm{kg} \mathrm{m}^{-2} \mathrm{~s}^{-1}\right)$ \\
\hline$G R$ & Subcooling degree $(\mathrm{K})$ \\
\hline GS & Superheating degree (K) \\
\hline$h$ & Specific Enthalpy $\left(\mathrm{J} \mathrm{kg}^{-1}\right)$ \\
\hline$k$ & Thermal conductivity $\left(\mathrm{W} \mathrm{m}^{-1} \mathrm{~K}^{-1}\right)$ \\
\hline$n$ & Number of experimental data \\
\hline$N T U$ & Number of heat transfer units \\
\hline$P$ & Pressure $(\mathrm{kPa})$ \\
\hline Pr & Prandtl number \\
\hline$\dot{Q}$ & Thermal power $(\mathrm{W})$ \\
\hline$q^{\prime \prime}$ & Heat flux $\left(\mathrm{W} \mathrm{m}^{-2}\right)$ \\
\hline $\mathrm{Re}$ & Reynolds number \\
\hline$T$ & Temperature $(\mathrm{K})$ \\
\hline$U$ & Overall HTC $\left(\mathrm{W} \mathrm{m}^{-2} \mathrm{~K}^{-1}\right)$ \\
\hline$\dot{V}$ & Volumetric flow rate $\left(\mathrm{m}^{3} \mathrm{~h}^{-1}\right)$ \\
\hline$x$ & Vapor quality \\
\hline$X_{t}$ & Martinelli parameter \\
\hline \multicolumn{2}{|c|}{ Greek symbols } \\
\hline$\alpha$ & Heat transfer coefficient $\left(\mathrm{W} \mathrm{m}^{-2} \mathrm{~K}^{-1}\right)$ \\
\hline$\delta$ & Liquid film thickness (m) \\
\hline$\varepsilon$ & Effectiveness \\
\hline$\mu$ & Dynamic viscosity ( $\mathrm{Pa} \mathrm{s}$ ) \\
\hline$\theta$ & Standard deviation \\
\hline$\rho$ & Density $\left(\mathrm{kg} \mathrm{m}^{-3}\right)$ \\
\hline$\sigma$ & Surface tension $\left(\mathrm{N} \mathrm{m}^{-1}\right)$ \\
\hline$\omega$ & Mean error \\
\hline$|\bar{\omega}|$ & Absolute mean error \\
\hline \multicolumn{2}{|c|}{ Subscripts } \\
\hline bee & Brine at the inlet \\
\hline bse & Brine at the outlet \\
\hline$c b$ & Convective boiling \\
\hline evap & evaporator \\
\hline$i$ & Inlet \\
\hline
\end{tabular}




\begin{tabular}{|ll|}
\hline$k$ & Condenser \\
$l$ & Liquid \\
$l v$ & Liquid-vapor \\
$n b$ & Nucleate boiling \\
& \\
Abbreviatures & \\
GHG & GreenHouse Gas \\
GWP & Global Warming Potential \\
HFC & HydroFluoroCarbon \\
HFO & HydroFluoroOlefines \\
HTC & Heat Transfer Coefficient \\
ODP & Ozone Depletion Potential \\
\hline
\end{tabular}

\section{Introduction}

During the last decades, R134a, R404A and R507A have being used in different refrigeration and air conditioning applications as non-ozone depleting R12 [1] and R22 [2] substitutes, respectively. They present good energy performance, are non-toxic and non-flammable. However, due to the Kyoto Protocol approval [3], they have been identified as Greenhouse Gas (GHG) as the rest of HFCs (HydroFluoroCarbon).

In order to enforce that agreed at the Kyoto Protocol, the European Union approved the Directive 2006/40/EC in 2006 [4], also known as F-gas Regulation. This Directive affected refrigerants with a GWP (Global Warming Potential) higher than 150 in new vehicles from 2011 and in all new vehicles produced from 2017. Then, in 2014, the Directive 2006/40/EC has been replaced by the Regulation (EU) No 517/2014, which bans the use of HFC with high GWP values in rest of refrigeration and air conditioning systems [5].

Considering the very large refrigeration applications using the vapour compression system, several low GWP refrigerant fluids with different characteristics can be found to replace HFCs in vapour compression systems, both natural and synthetic, [6].Natural refrigerants comprise hydrocarbons, flammable but economical and energy efficient; carbon dioxide, increasingly relevant used in transcritical or cascade systems; and ammonia, toxic and flammable but very efficient. Synthetic refrigerants are considered good low and mid-term alternatives and can be differenced in low-GWP HFCs, HFOs (HydroFluoroOlefines) or mixtures of both groups.

Two HFOs appeared as R134a replacements [7]: R1234yf [8] and R1234ze(E) [9]. They present low-flammability, they are non-toxic and its GWP values are 4 and 6 (accomplishing GWP limitations), respectively. R1234yf has been proposed as R134a drop-in substitute in mobile air conditioning applications [10] and R1234ze(E) can be used in chillers [11] and heat pumps [12], among others applications. 
Although R1234ze(E) shows relevant advantages in refrigeration systems, it is not recommended its use as R134a drop-in replacement because it presents lower cooling capacity [13] and low-flammability [14]. With the purpose of found a most satisfactory solution (non-flammable, lower GWP values, with acceptable cooling capacity) and extend the lower GWP refrigerants usage for substitution of another HFC (as R404A and R410A), it has been mixed with some HFC [15].

In this way, blends like R444A, R445A and R450A appeared as alternatives to substitute the refrigerant R134a. Focusing on blend R450A, it is a mixture of $\mathrm{R} 1234 \mathrm{ze}(\mathrm{E})$ and R134a (58/42 in \%mass) intended to replace R134a in medium temperature applications (chillers, heat pumps and commercial refrigeration, among other) [16]. It is non-flammable and its GWP is 549 (though it is not enough low for some cooling systems in Europe). It have shown good efficiency compared to R134a, as demonstrate Mota-Babiloni et al. [17] in a vapour compression test rig and Tewis Smart solutions [18] or Honeywell [19] in a supermarket cascade systems. Lower performance has shown in a water-cooled screw chiller installation [20].

In the other way, R448A appears as a blend alternative to substitute the R404A and it is composed of R32/R125/R134a/R1234yf/R1234ze(E) (26/26/20/21/7 in \%mass) resulting non-flammable and GWP of 1205. R448A can substitute R404A in large centralized systems at low and medium evaporating conditions [20]. As happens for R450A, this HFO/HFC mixture also presents good performance. Mota-Babiloni et al. [22] studied theoretically six R404A alternatives in four vapour compression configurations, obtaining high efficiency simulating with R448A. Yana Motta [23], using a $2.2 \mathrm{~kW}$ semi-hermetic condensing unit with evaporator for walk-in freezer/cooler, show that R448A matches the capacity of R404A with $6 \%$ higher efficiency. Rajendran [24] obtained lower energy consumption for R448A (3\% to 8\%) in a scroll compressors centralized Direct Expansion system with cases and food simulators. Abdelaziz and Fricke [25], in a test facility that uses reciprocating compressors and two separate temperature/humidity controlled rooms, found that refrigerant R448A average energy efficiency was $11.6 \%$ higher than that obtained with R404A.

When designing vapour compression systems, the evaporator selection is one of the most important parts [26]. One of the main parameters in evaporator design is the flow boiling heat transfer coefficient (HTC) and depends on the evaporator geometry and the refrigerant properties [27]. Flow boiling HTC can be determined accurately through steady-state evaporator models, as demonstrated, for example, by Navarro-Esbrí et al. [28] or Zhao et al. [29] for R1234yf and R134a.

R450A and R448A are promising alternatives to two of most currently used refrigerants, $\mathrm{R} 134 \mathrm{a}$ and R404A, due to its similar properties, Table 1. The problem is that the there are few data available for both alternative refrigerants and the effect of replace HFCs cannot be predicted properly. In this paper a shell-and-micro-fin tubes evaporator model 
is validated and used to evaluate these refrigerants considering different relevant heat exchanger parameters. The most accurate model is applied to compare the evaporator performance between these refrigerants. The conclusions of this work can be used in the evaluation of HFCs substitution or in the refrigeration system and heat exchanger design using R450A and R448A, two refrigerants that can achieve great GWP reductions and therefore, lessen the global warming.

The rest of the paper is structured as follows: In section 2, the experimental setup, refrigerants and test performed are presented. In section 3, the evaporator model is mentioned. In section 4, the correlations selected are exposed. In section 5, the results of the study are discussed. Finally, in section 6, the main conclusions are summarized.

\section{Experimental setup}

\subsection{Test bench}

The test bench used in this work is a fully monitored vapour compression plant that consists of a main circuit and two secondary circuits, Figure 1. The vapour compression system is composed of the following components:

- Reciprocating open compressor, driven by variable-speed $7.5 \mathrm{~kW}$ electric motor using polyolester (POE) oil as lubricant. The compressor speed can be selected using an inverter.

- Shell-and-smooth tubes condenser (1-2), with refrigerant flowing along the shell and the water (used as secondary fluid) inside the tubes.

- Shell-and-micro-fin tubes evaporator (1-2), where the refrigerant flows inside the tubes and a water/propylene glycol mixture (65/35 by volume) along the shell.

- Thermostatic expansion valve.

- Corrugated counter flow tube-in-tube internal heat exchanger (also known as suction-line/liquid-line heat exchanger), which is activated or deactivated by a set of solenoid valves.

The secondary circuits fix the requested evaporating and condensing conditions:

- The heat removal circuit is formed of a heat load circuit is composed by a set of immersed electrical resistances regulated by a Proportional Integral Derivative (PID) controller. 
- The heat removal circuit uses a fan and an auxiliary chiller.

- In both circuits the secondary fluid flow rate can be adjusted using a variablespeed pump.

The main characteristics of the evaporator (and micro-fin tube) geometry are listed in Table 2.

As mentioned before the test bench is completely monitored to obtain the main thermodynamic parameters (through temperature and pressure measurements) at the inlet and outlet of each main component (the location of sensors can be seen in Fig. 1). The system also contains a Coriolis flow meter in main circuit and two electromagnetic flow meters in secondary circuits. The compressor power consumption and rotation speed are also measured for energetic calculations. Detailed information about sensors is listed in Table 3.

Finally, all data generated by all sensors were gathered by a data acquisition system (every 0.5 seconds) and monitored and stored using a PC. The refrigerant thermodynamic states are calculated from REFPROP v9.1 database [30].

\subsection{Tests performed}

The tests conditions cover a complete mid (all refrigerants) and low (R448A and R404A) evaporation temperature range of vapour compression systems, Table 4.

The evaporating pressure is defined considering glide effects on heat exchangers, Eq. (1) is applied to correct R450A and R448A evaporating pressure [15, 22].

$$
P_{e v a p}=\frac{1}{3} P_{b u b b l e}+\frac{2}{3} P_{d e w}
$$

\section{Evaporator model}


The model is based on the thermal analysis $\varepsilon$-NTU method, correlations used to determine convective heat transfer coefficients and the data provided by the evaporator manufacturer (Table 2). The evaporator is modeled by dividing it into two zones that correspond to the state of the refrigerant, i.e., evaporation and superheating zones. The complete evaporator model (development, assumptions, and equations, etc.) is explained and analysed in Mendoza-Miranda et al. [31]. The overall heat transfer coefficient is calculated using Eq. (2) which includes the thermal resistance associated to the fouling on the shell side, $R_{0, \mathrm{e}}$. This value is $0.000086 \mathrm{~m}^{2} \mathrm{~K} \mathrm{~W}^{-1}$ for water/propylene-glycol brine containing below $40 \%$ of propylene glycol according to the manufacturer data.

$U_{z o n e}=\left\{\left(\frac{1}{\alpha_{i, z o n e}}\right)\left(\frac{d_{o}}{d_{i}}\right)+R_{o, e}+\frac{d_{o} \ln \left(\frac{d_{o}}{d_{i}}\right)}{2 k}+\frac{1}{\alpha_{o, b r i n e}}\right\}$

The internal heat transfer coefficient, $\alpha_{i, z o n e}$, in single phase for turbulent flow for micro-fin tubes is given by the Jensen and Vlakancic correlation [32] defined as:

$$
\begin{aligned}
& \alpha_{i}=\left(\frac{k}{d_{i}}\right) F_{1}^{-0.5} F_{2}\left(\frac{0.25 \pi d_{i}^{2}}{0.25 \pi d_{i}^{2}-N_{f} \cdot e \cdot t}\right)^{0.8} \mathrm{Nu}_{s}
\end{aligned}
$$

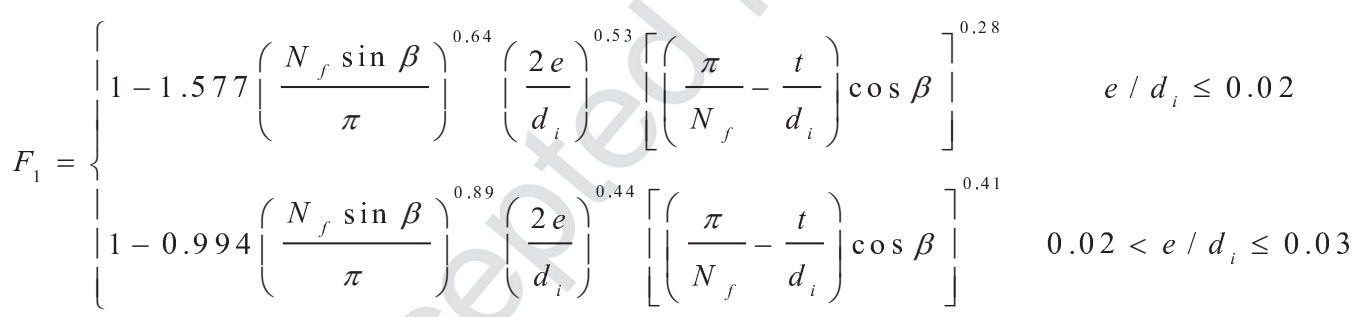

$$
\begin{aligned}
& F_{2}=\left(1+\frac{2 N_{f} \cdot e}{\pi d_{i}}\right)\left\{1-0.059\left(\frac{N_{f} \sin \beta}{\pi}\right)^{-0.31}\left\lceil\left(\frac{\pi}{N_{f}}-\frac{t}{d_{i}}\right) \cos \beta\right]^{-0.66}\right)
\end{aligned}
$$

Where $N u_{s}$ is obtained from the Gnielinskis' correlation [33] for a smooth tube defined as:

$$
\mathrm{Nu}_{s}=\frac{(f / 2)(\mathrm{Re}-1000) \mathrm{Pr}}{1+12.7(f / 2)^{1 / 2}\left(\mathrm{Pr}^{2 / 3}-1\right)}
$$

Where

$$
f=[1.58 \ln (\mathrm{Re})-3.28]^{-2}
$$


For the external forced convection on the array of tubes the Zhukauskas' correlation [34], Eq. (8), is used.

$\alpha_{o, b \text { rine }}=C \operatorname{Re}^{m} \operatorname{Pr}^{0.36}\left(\frac{\operatorname{Pr}}{\operatorname{Pr}_{w}}\right)^{1 / 4}\left(\frac{k_{f}}{d_{o}}\right)$

Where coefficients, $C$ and $m$, are estimated according to the Reynolds number.

The model input parameters are mass flow rate, and inlet enthalpy for refrigerant; and volumetric flow rate and inlet temperature for the brine. The model outputs are evaporating pressure, outlet enthalpy for the refrigerant, outlet brine temperature, heat transfer areas dedicated to boiling and superheating as well as the cooling capacity.

\section{Flow boiling correlations}

The two-phase flow heat transfer coefficient of the refrigerant is one of the most important issues in the evaporator design. There are available in the literature different methods (or correlations) to calculate the flow boiling heat transfer coefficient. The final method selected will depend on the evaporator geometry, working fluid and predominant evaporation region.

There are different mechanisms to enhance heat transfer coefficient in evaporators [35]. Add micro-fins to tubes of evaporators can produce thermal advantages (though pressure losses are incremented) [36]. As compared to smooth tubes, microfin tubes ensure a large heat transfer enhancement with a relatively low pressure drop increase and reduce the range of operating conditions leading to dry-out and partial dry-out. The presence of micro-fins may change the two-phase flow pattern and the relative importance of nucleate boiling and convective evaporation heat transfer mechanisms [37].

Diverse boiling flow heat transfer coefficient correlations for micro-fin tubes have been proposed in the past years. However, most of them have not been tested with experimental data using the considered mixtures. In this paper the models proposed by Koyama et al. [38], Yun et al. [39], and Akhavan-Behabadi et al. [40] are selected to analyse the model accuracy using R134a, R450A, R404A and R448A in the evaporator.

The Koyama et al. [38] adapted Chen correlation, presenting a superposition-type model that considers the enhancement effect of micro-fins on the convective heat transfer and the nucleate boiling component. It presented good results for R22, R134a and R123 at mass velocity from 200 to $400 \mathrm{~kg} \mathrm{~m}^{-2} \mathrm{~s}^{-1}$, heat fluxes from 5 to $64 \mathrm{~kW} \mathrm{~m}$-2 and reduced pressure from 0.07 to 0.24 . Due to the great amount of equations, this micro-fin model is detailed in Table 5. 
The Yun et al. [39] model implemented non-dimensional parameters accounting for heat transfer enhancement over smooth tubes and physical phenomena into the basic form of a smooth tube correlation. They used a great amount of experimental points to obtain the correlation agreement and the average deviation was $-11.7 \%$. The equations that represent this model are Eq. (9) to (11):

$$
\begin{aligned}
& \left.\alpha_{T P}=\alpha_{l} \mid C_{1} \mathrm{~B} \mathrm{o}^{C_{2}}\left(\frac{P_{e v a p} d_{i}}{\sigma}\right)^{C_{3}}+C_{4}\left(\frac{1}{X_{t}}\right)^{C_{5}}\left(\frac{G \cdot e}{\mu_{l}}\right)^{C_{6}}\right] \operatorname{Re}_{l}^{C_{7}} \operatorname{Pr}_{l}^{C_{8}}\left(\frac{\delta}{e}\right)^{C_{9}} \\
& \mathrm{~B} \mathrm{o}=\frac{q^{\prime \prime}}{G h_{l v}} \\
& \alpha_{l}=0.023 \mathrm{Re}_{l}^{0.8} \operatorname{Pr}_{l}^{0.4}\left(\frac{k_{l}}{d_{i}}\right)
\end{aligned}
$$

Finally, Akhavan-Behabadi et al. [40] developed a correlation based on their R134a experimental results, to predict the micro-fin HTC at four different mass velocities (53, 80,107 and $136 \mathrm{~kg} \mathrm{~m}^{-2} \mathrm{~s}^{-1}$ ) and tube inclinations (from $-90^{\circ}$ to $+90^{\circ}$ ). They obtained good agreement between the correlation and experimental values (an error band of $\pm 10 \%$ ). In the case of a horizontal tube the correlation results in Eq. (12) and (13).

$$
\begin{aligned}
& \alpha_{T P}=4.05 \times 10^{-3} \mathrm{Re}_{l}^{0.98} F_{\alpha}^{0.38}(1.55-x)^{0.96}\left(\frac{\mathrm{Pr}_{l}}{X_{t t}}\right)^{1.09} \\
& F_{\alpha}= \begin{cases}1 & x \leq 0.7 \\
1+0.2 x^{1.2} \cos (15 \pi / 180) & x>0.7\end{cases}
\end{aligned}
$$

Although they are not studied here, other micro-fin tubes model can be found in literature as those developed by Thome et al. [41] and Cavallini et al. [42]. Thome's correlation was the first developed introducing the geometrical dimensions of microfins and it considers the aggrandizement of nucleate boiling and convective evaporation caused by micro-fins. The Cavallini's model considers heat transfer mechanisms: nucleate boiling, convective evaporation and capillarity. 


\section{Results and discussion}

\subsection{Model validation}

In order to check the predictive ability of the three flow boiling heat transfer correlations used in the evaporator model, three operational parameters of the evaporator have been selected: evaporating pressure, two-phase overall heat transfer coefficient (UA $\mathrm{UA}_{\mathrm{TP}}$ product) and cooling capacity. Thus, Table 7 provided a summary of the statistical analysis in order to check the evaporator simulation versus experimental data using all flow boiling correlation provided. To do so, Eqns. $(14-17)$ [43] are used to quantify its individual error (Eq. 14), mean error (Eq. 15), absolute mean error (Eq. 16) and standard deviation (Eq. 17) for predicted evaporating pressure, $\mathrm{UA}_{\mathrm{TP}}$ product and cooling capacity, respectively.

$$
\begin{array}{r}
\omega_{i}=\frac{\text { Model value }- \text { experimental value }}{\text { experimental value }} \\
\bar{\omega}=\frac{1}{n} \sum_{i=1}^{n} \omega_{i} \\
|\bar{\omega}|=\frac{1}{n} \sum_{i=1}^{n} \omega_{i} \\
\theta=\sqrt{\frac{1}{n} \sum_{i=1}^{n}\left(\omega_{i}-\bar{\omega}\right)^{2}}
\end{array}
$$

Although R134a is studied in Mendoza-Miranda et al. [31], it is also displayed here to compare this results (pure refrigerant) with the performed using the other refrigerants (near-azeotrope and non-azeotrope mixtures). Moreover, all the correlations used in this paper were validated by their authors using R134a, so it could suggest the magnitude of the deviation for the other refrigerants.

Figs. 2 - 4 show comparisons of measured and predicted data for the four refrigerant tested (R134a, R404A, R448A, R450A) and the flow boiling heat transfer correlations for micro-fin tubes developed by Koyama et al.[38], Yun et al. [39] and AkhavanBehabadi et al. [40]. Fig. 2a highlights the measured evaporating pressure for each refrigerant and all boiling heat transfer correlations. It can be seen that the results agree 
quite well, with $82 \%$ of the points predicted to an accuracy of $\pm 10 \%$ using the three correlations studied. It appears that the model using the Akhavan-Behabadi et al. correlation slightly under predicts the evaporating pressure for low-load conditions using R134a; however, prediction is still within the error bandwidth. Fig. $2 b$ shows a similar comparison for the R450A obtaining that the results agree with 32\%, 59\% and $91 \%$ of the points predicted to an accuracy of $\pm 10 \%$ using Koyama, Yun and AkhavanBehabadi correlations, respectively. Koyama and Yun correlations over predict the evaporating pressure when evaporating pressure increase meanwhile the AkhavanBehabadi et al. correlation shows a slight over prediction (compared with the first two correlations) when evaporating pressure increases. Similar results are obtained for R404A and R448A (Figs. 2c and 2d) highlighting that for high evaporating pressure using R404A the over prediction increase up to 13\% using Koyama correlation, 9\% with Yun correlation and $7.7 \%$ with Akhavan-Behabadi correlation.

Fig 3 shows the comparison between the product of two-phase overall heat transfer coefficient and heat transfer area $\left(\mathrm{UA}_{\mathrm{TP}}\right)$ for each refrigerant. In this case, the points observed are more scattered than those observed in evaporating pressure. For Koyama and Yun flow boiling correlations, the values are generally over predicted, meanwhile for Akhavan-Behabadi correlation we obtained a best fits of our experimental data.

Finally, cooling capacity is the parameter that shows the most precise predictions, as all the values remains inside the $\pm 10 \%$ error bandwidth, as shown in Fig. 4. Standard deviations are below 1.5\% for all refrigerants using Akhavan-Behabadi et al. correlation and for the Koyama correlation, the highest deviation obtained is $1.8 \%$ for R404A. The values are generally over predicted except for R134a using Akhavan-Behabadi et al. correlation. As observed before, the highest deviations are obtained at higher cooling capacities (same tests that higher evaporating pressures).

$\mathrm{R} 450 \mathrm{~A}$ is the first near-azeotrope mixture studied; as happens for R134a, values are over predicted for all the correlations, being the large deviation that obtained with Koyama correlation. Intermediate deviation is obtained with Yun correlation and the correlation that best fits to the experimental results is Akhavan-Behabadi. For $p_{\text {evap }}$ and $\mathrm{UA}_{\mathrm{TP}}$ almost the half of the values are within $\pm 10 \%$, being the high deviation at higher $\mathrm{p}_{\text {evap }}$, aditianally, all $\mathrm{Q}_{\text {ref }}$ predictions are inside the $\pm 10 \%$ error bandwidth. In the other hand, similar results are obtained for the R448A zeotropic refrigerant mixture. 


\subsection{Evaporator performance}

Once the evaporator model has been validated with the experimental results, this section compares the evaporator performance between the HFCs selected and their replacements. Because Akhavan-Behabadi et al. correlation provides the most precise predictions; the simulations have been performed applying this model. The comparison is performed at refrigerant mass flow rates between 0.025 and $0.09 \mathrm{~kg} \mathrm{~s}^{-1}$. The input conditions of the comparison are indicated in Figure 5, which shows the main results of the simulation.

The evaporating temperature (Fig 5.a) decreases with the increase of mass flow rate. In the case of R448A this evaporation temperature is the lower due to the large glide effects that therefore is going to be reflected in a difference in evaporation pressure and compression ratio. The rest of refrigerants display higher evaporation temperatures, being that of R404A the higher at high mass flow rates. Then, Fig. 5(b) presents the variation of the temperature of the brine at the evaporator inlet. It also presents a high difference between R404A and R448A due to the large R448A glide. Both, $\mathrm{T}_{\text {evap }}$ and $\mathrm{T}_{\text {bse }}$ will imply a very different pinch point between $\mathrm{R} 404 \mathrm{~A}$ and its alternative. The difference between R134a and R450A can be considered small, $0.6 \mathrm{~K}$ as average, mainly due to the R1234ze(E) inclusion in the mixture.

Fig 5.(c) represents the evaporator effectiveness at flow boiling, which is very similar for refrigerants R134a and R450A, and lies between 30 and 50\% approximately. The effectiveness of R448A is above that performed by R404A, 5\% as average, and indicates that the flow boiling HTC of both refrigerants are significantly different. Finally, the cooling capacity during evaporation of the fluids analyzed is shown in Fig. 5(d). As the rest of parameters, R450A cooling capacity is very similar to that of R134a (especially at great mass flow rates). On the other hand, R448A cooling capacity is between $1.2 \mathrm{~kW}$ and $3.4 \mathrm{~kW}$ greater than that of $\mathrm{R} 404 \mathrm{~A}$, affected directly by higher R448A evaporating enthalpy difference.

\section{Conclusions}

In this paper a micro-fin tubes evaporator performance evaluation using two new lowGWP alternatives, R450A and R448A, and their baselines, R134a and R404A, was presented. The comparison was made using results obtained from a steady-state evaporator model. This model was validated using experimental measurements from a shell-and- micro-fin tube evaporator located in an experimental vapour compression system. Tests were carried out varying parameters as evaporating pressure, mass flow rate or superheating degree, among others. The main conclusions of the work are summarized as follow. 
The best predictions performed by the model are observed when Akhavan-Behabadi et al. correlation is used, then Yun and finally Koyama. The use of Akhavan-Behabadi et al. correlation allows obtaining great quantity of points inside the $\pm 10 \%$ limits and lower mean error and standard deviation values. The deviation is low at lower evaporation temperatures (low mass flow rates and cooling capacity).

This micro-fin-tubes evaporator model presented predicts accurate for all refrigerants tested, for the higher precision of the model is observed for R450A and R404A (nearazeotropic mixtures), then R448A (azeotropic mixture) and finally R134a. The error observed is higher for $\mathrm{UA}_{\mathrm{TP}}$ than evaporating pressure or cooling capacity, so this model is recommended to study operating conditions or evaporator energetic performance.

Evaporator performance of R450A is very similar to that of R134a although it only presents $42 \%$ of R134a in its composition. Besides, R404A and R448A presents a great difference for all parameters studied, mostly caused by glide effects, different HTC and enthalpy difference.

\section{Acknowledgements}

The authors thankfully acknowledge "Ministerio de Educación, Cultura y Deporte" (Grant number FPU12/02841) for supporting this work through "Becas y Contratos de Formación de Profesorado Universitario del Programa Nacional de Formación de Recursos Humanos de Investigación del ejercicio 2012”. Finally the linguistic support of Irene I. Elías-Miranda is appreciated.

\section{References}

[1] E. Halimic, D. Ross, B. Agnew, A. Anderson and I. Potts, "A comparison of the operating performance of alternative refrigerants", App. Therm. Eng., vol. 23, pp. 1441-1451, 2003.

[2] A. da Silva, E.P. Bandarra Filho and A.H. Pontes Antunes, "Comparison of a R744 cascade refrigeration system with R404A and R22 conventional systems for supermarkets", App. Therm. Eng., vol. 41, pp. 30-35, 2012.

[3] Kyoto Protocol, "Report of the Conference of the Parties," United Nations Framework Convention on Climate Change (UNFCCC), 1997.

[4] "Directive 2006/40/EC of The European Parliament and of the Council of 17 May 2006 relating to emissions from air-conditioning systems in motor vehicles and amending Council Directive 70/156/EC," Off. J. of the European Union, 2006.

[5] "Regulation (EU) No 517/2014 of the European Parliament and the Council of 16 April 2014 on fluorinated greenhouse gases and repealing Regulation (EC) No 842/2006," Off. J. of the European Union, 2014. 
[6] A. Mota-Babiloni, J. Navarro-Esbrí, Á. Barragán-Cervera, F. Molés, B. Peris, G. Verdú, "Commercial refrigeration - An overview of current status", Int. J. Refrig., vol. 57, pp. 186-196, 2015.

[7] F. Molés, J. Navarro-Esbrí, B. Peris, A. Mota-Babiloni and Á. Barragán-Cervera, "Theoretical energy performance evaluation of different single stage vapour compression refrigeration configurations using R1234yf and R1234ze(E) as working fluids," Int. J. Refrig., vol. 44, pp. 141-150, 2014.

[8] B. Minor and M. Spatz, "A Low GWP Refrigerant for MAC," in 2nd International Workshop on Mobile Air Conditioning and Auxiliary Systems, Torino, Italy, 2007.

[9] Honeywell International Inc, "Solstice ${ }^{\mathrm{TM}}$ ze (HFO-1234ze) Refrigerant. The environmental alternative to traditional refrigerants," 2012. Retrieved online at: http://www.honeywell-refrigerants.com/india/?document=solstice-ze-hfo1234ze-brochure-2012\&download=1, 27 October 2014.

[10] M. Koban, "Automotive material investigation with low GWP refrigerant HFO1234yf," in Vehicle Thermal Management Systems Conference and Exhibition (VTMS10), Nottingham, United Kingdom, 2011.

[11] K. Schultz and S. Kujak, "Low GWP AREP R134a W/C Screw Chiller Test Summary - Final Report," Air-Conditioning, Heating, and Refrigeration Institute (AHRI) Low-GWP Alternative Refrigerants Evaluation Program (LowGWP AREP), Test Report \#7, 2012.

[12] S. Fukuda, C. Kondou, N. Takata and Shigeru Koyama, "Low GWP refrigerants $\mathrm{R} 1234 \mathrm{ze}(\mathrm{E})$ and R1234ze(Z) for high temperature heat pumps", Int. J. Refrig., vol. 40, pp. 161-173, 2014.

[13] A. Mota-Babiloni, J. Navarro-Esbrí, Á Barragán, F. Molés and B. Peris, "Dropin energy performance evaluation of R1234yf and R1234ze(E) in a vapour compression system as R134a replacements," App. Therm. Eng., vol. 71, pp. 259-265, 2014.

[14] S. Kondo, K. Takizawa and K. Tokuhashi, "Flammability limits of binary mixtures of ammonia with HFO-1234yf, HFO-1234ze, HFC-134a, and HFC125," J. Fluorine Chem., vol. 149, pp.18-23, 2013.

[15] A. Mota-Babiloni, J. Navarro-Esbrí, Á. Barragán-Cervera, F. Molés and B. Peris, "Analysis based on EU Regulation No 517/2014 of new HFC/HFO mixtures as alternatives of high GWP refrigerants in refrigeration and HVAC systems," Int. J. Refrig. vol. 52, pp. 21-31, 2015.

[16] Honeywell, "Solstice family of HFOs", 2013, Retrieved online at; http://www.racplus.com/Journals/2012/06/01/g/s/r/Honeywell-presentation.pdf, 5 June 2014.

[17] A. Mota-Babiloni, J. Navarro-Esbrí, Á. Barragán-Cervera, F. Molés, B. Peris, "Experimental study of an R1234ze(E)/R134a mixture (R450A) as R134a replacement", Int. J. Refrig. vol. 51 pp. 52-58, (2015). 
[18] Tewis Smart Solutions, "El rigor y metodología demuestran los beneficios del R450A* (Solstice ${ }^{\circledR}$ N13) en su carrera hacia un futuro", 2014, Retrieved online at: http://www.tewis.com/newtewis/blog/descargas/Tewis_Mayo 14.pdf, 12 April 2015.

[19] Honeywell International Inc, "Solstice ${ }^{\circledR}$ N13 (R-450A). Innovative Refrigeration System, Combining the 'Best of Both Worlds' ", 2014, Retrieved online at: $\quad$ http://www.honeywell-refrigerants.com/europe/wpcontent/uploads/2014/10/Case_Study_Groupe_Auchan_Solstice_N13_4pp_LR140923.pdf, 12 April 2015.

[20] K. Schultz and S. Kujak, "System Drop-In Tests of R134a Alternative Refrigerants (ARM-42a, N-13a, N-13b, R-1234ze(E), and OpteonTM XP10) in a 230-RT Water-Cooled Water Chiller", Air-Conditioning, Heating, and Refrigeration Institute (AHRI) Low-GWP Alternative Refrigerants Evaluation Program (Low-GWP AREP), TEST REPORT \#, 2013.

[21] Honeywell International Inc, "Honeywell Solstice ${ }^{\mathrm{TM}}$ N40 Refrigerant Improved Energy Efficiency Case Study, Gaining Competitive Advantage through Improved Energy Efficiency and Reduced Environmental Impact”, 2012, Retrieved online at: http://www.honeywellrefrigerants.com/india/resources/customer-case-studies/honeywell-solstice-n40improved-energy-efficiency-case-study/, 25 March 2014.

[22] A. Mota-Babiloni, J. Navarro-Esbrí, Á. Barragán, F. Molés and B. Peris, "Theoretical comparison of low GWP alternatives for different refrigeration configurations taking R404A as baseline", Int. J. Refrig. vol. 44 pp. 81-90, 2014.

[23] S.F. Yana Motta, M.W. Spatz, G. Pottker and G.L. Smith, "Refrigerants with Low Environmental Impact for Refrigeration Applications", International Refrigeration and Air Conditioning Conference, Paper 1554, 2014, http://docs.lib.purdue.edu/iracc/1554.

[24] R. Rajendran, "Promising Lower GWP Refrigerants In Air-Conditioning And Refrigeration Systems, Advancing Ozone \& Climate Protection Technologies: Next Steps - Second International Conference (UNEP)", Emerson Climate Technologies, Bangkok, 2013.

[25] O. Abdelaziz and, B. Fricke, "Working Fluids: Low Global Warming Potential Refrigerants, 2014 Building Technologies Office Peer Review - US Department of Energy", Oak Ridge National Laboratory, Arlington-VA, 2014.

[26] I. Dinçer and M. Kanoglu, "Refrigeration systems and applications (Second Edition)," John Wiley \& Sons Ltd, Chichester, United Kingdom, 2010.

[27] R.W. Serth and T.G. Lestina, "9 - Boiling Heat Transfer," in Process Heat Transfer (Second Edition), pp. 317-360, Academic Press, Boston, 2014. 
[28] J. Navarro-Esbrí, F. Molés, Á. Barragán, A. Mota-Babiloni, J. M. MendozaMiranda and J.M. Belman, "Shell-and-tube evaporator model performance with different two-phase flow heat transfer correlations. Experimental analysis using R134a and R1234yf", App. Therm. Eng., vol. 62, pp. 80-89, 2014.

[29] Y. Zhao, Y. Liang, Y. Sun and J. Chen, "Development of a mini-channel evaporator model using R1234yf as working fluid", Int. J. Refrig., vol. 35, pp. 2166-2178, 2012.

[30] E. W. Lemmon and M. L. McLinden, "Reference fluid thermodynamic and transport properties (REFPROP), version 9.1," in NIST Standard Reference Database 23, Gaithersburg, MD, 2014.

[31] J. M. Mendoza-Miranda, J. J. Ramírez-Minguela, V. D. Muñoz-Carpio and J. Navarro-Esbrí, "Development and validation of a micro-fin tubes evaporator model using R134a and R1234yf as working fluids," Int. J. Refrig., vol. 50, pp. 32-43, 2015.

[32] M. Jensen and A. Vlakancic, "Technical note - experimental investigation of turbulent heat transfer and fluid flow in internally finned tubes," Int. J. Heat Mass Transfer, vol. 42, pp. 1343-1351, 1999.

[33] V. Gnielinski, "New equations for heat and mass transfer in turbulent pipe and channel flow," Int. Chem. Eng., vol. 16, pp. 359-368, 1976.

[34] A. Zhukauskas, "Heat transfer from tubes in cross flow," in J.P. Hartnett, T.F. Irvine (Eds.), Adv. in Heat Transf., vol. 8, Academic Press, New York, 1972.

[35] M. Siddique, A.-R. A. Khaled, N. I. Abdulhafiz, and A. Y. Boukhary, "Recent Advances in Heat Transfer Enhancements: A Review Report International," $J$. Chem. Eng., vol. 2010, Article ID 106461 (28 pages), 2010.

[36] B. Sundén, Vishwas V. Wadekar and W. Li, "Heat Transfer Correlations for Single-Phase Flow, Condensation, and Boiling in Microfin Tubes," Heat Transfer Eng., vol. 36(6), pp. 582-595, 2015.

[37] A. Padovan, D. Del Col, L. Rossetto Experimental study on flow boiling of $\mathrm{R} 134 \mathrm{a}$ and R410A in a horizontal microfin tube at high saturation temperatures. App. Therm. Eng 31, pp. 3814 - 3826, 2011.

[38] S. Koyama, J. Yu, S. Momoki, T. Fujii and H. Honda, "Forced convective flow boiling heat transfer of pure refrigerants inside a horizontal microfin tube," in Proc. of the convective flow boiling, Alberta, 1995.

[39] R. Yun, Y. Kim, K. Seo and H. Y. Kim, "A generalized correlation for evaporation heat transfer of refrigerants in micro-fin tubes," Int. J. Heat Mass Transfer, vol. 45, pp. 2003-2010, 2002.

[40] M. A. Akhavan-Behabadi, S. G. Mohseni and S. M. Razavinasab, "Evaporation heat transfer of R-134a inside a microfin tube with different tube inclinations," Exp. Therm. Fluid Sci., vol. 35, pp. 996-1001, 2011.

[41] J.R. Thome, N. Kattan and D. Favrat, "Evaporation in microfin tubes: a generalized prediction model," in Proc. of Convect. Flow and Pool Boiling Conf., Irsee, Germany, 1997. 
[42] A. Cavallini, D. Del Col and L. Rosseto, "Flow boiling inside microfin tubes: prediction of the heat transfer coefficient," in Proc. of ECI International, Spoleto, Italy, 2006.

[43] G. Bohm, G. Zech, "Introduction to Statistics and Data Analysis for Physicists (First Edition)," Deutsches Elektronen-Synchrotron, Hamburg, Germany, 2010. 


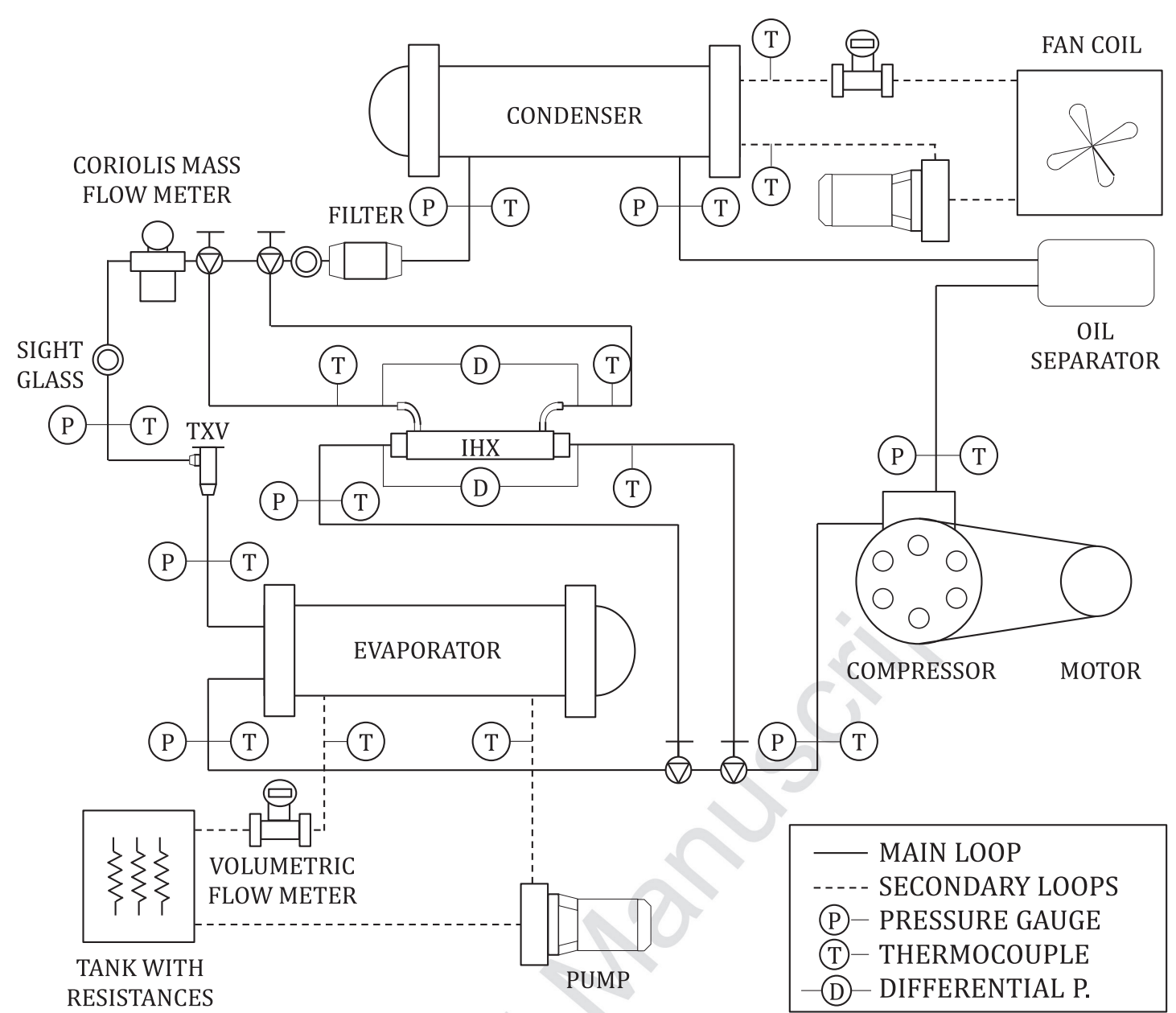

Figure 1. Test bench schematic diagram. 


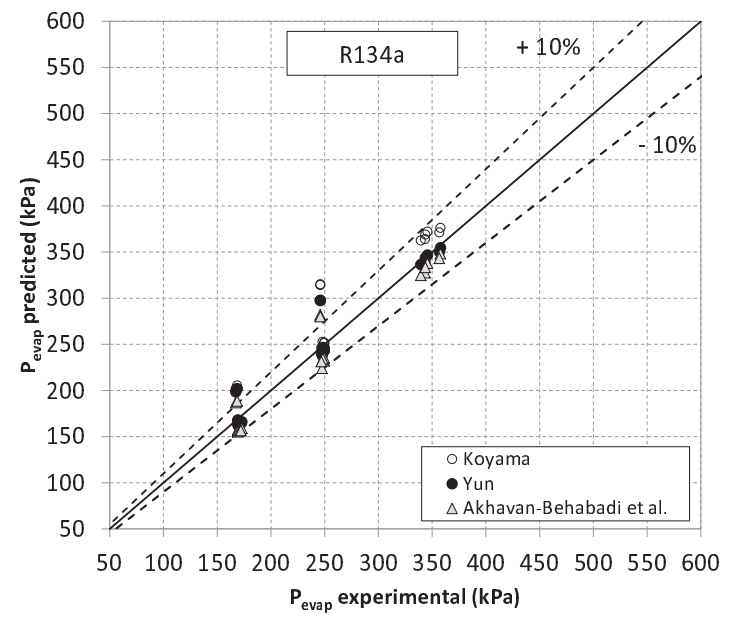

a)

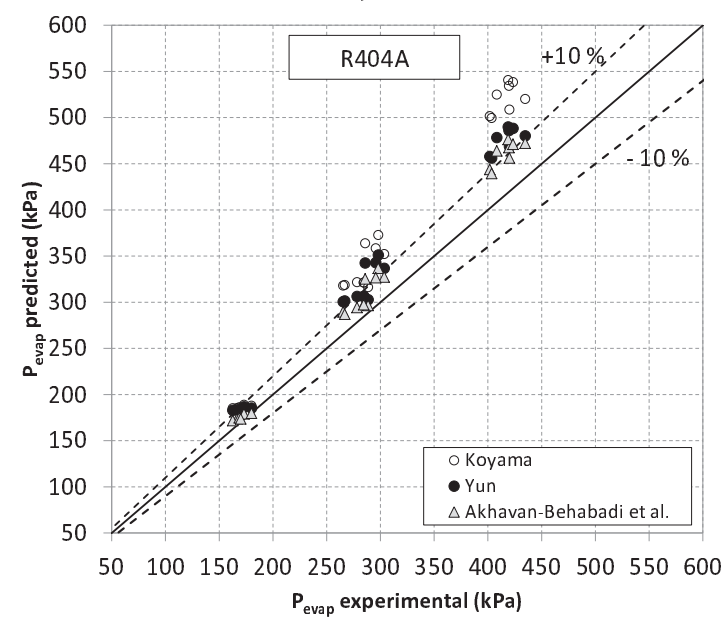

c)

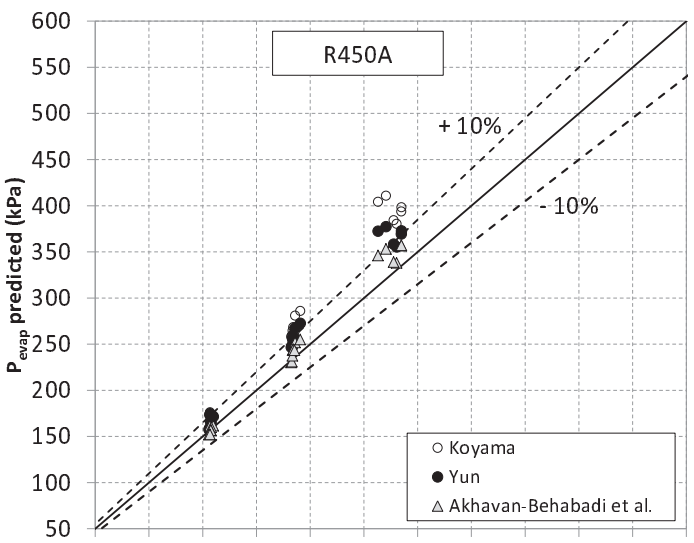

$50 \quad 100150200 \quad 250300 \quad 350400 \quad 450500550600$ $\mathrm{P}_{\text {evap }}$ experimental (kPa)

b)

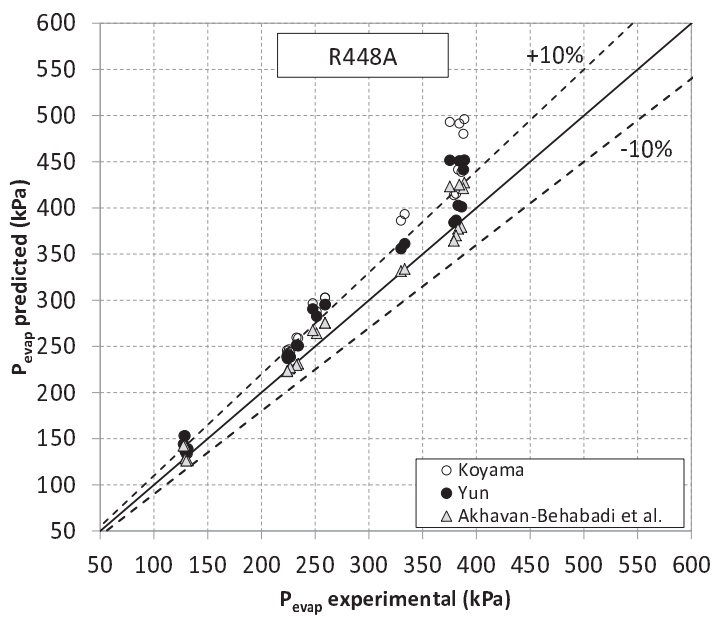

d)

Figure 2. Evaporating pressure model deviations for: a) R134a, b) R450A, c) R404A and d) R448A. 


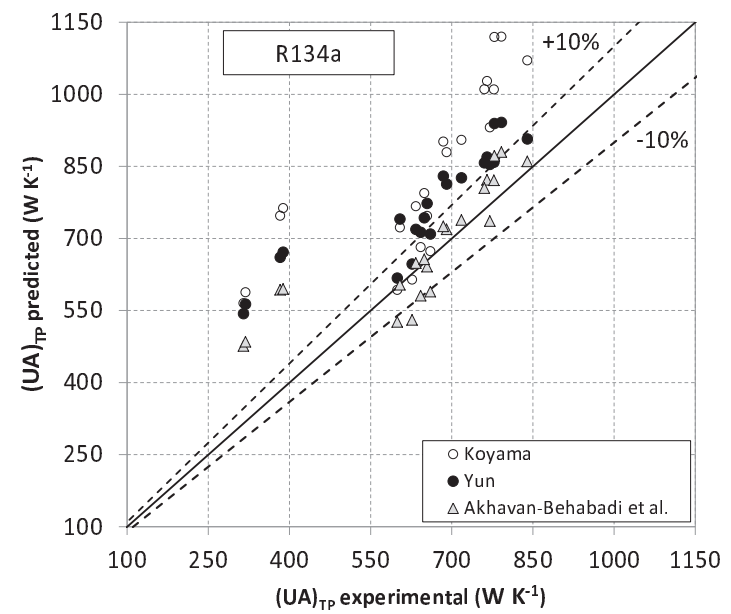

a)

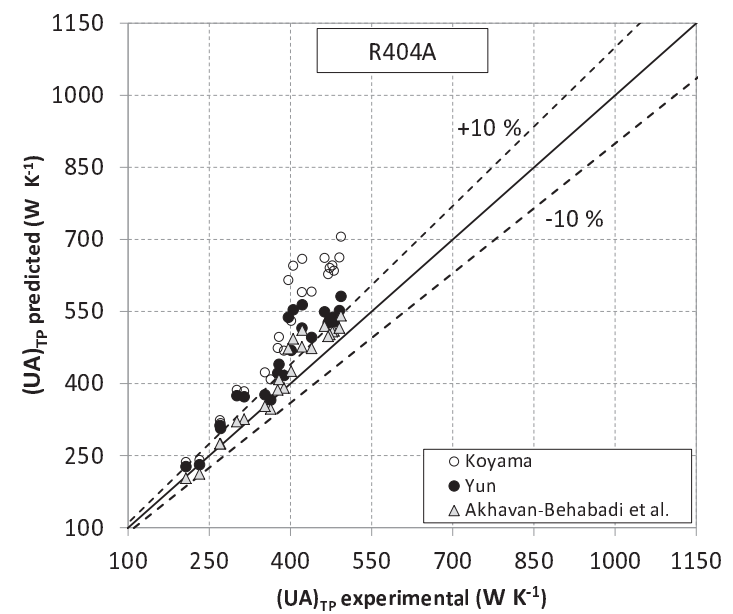

c)

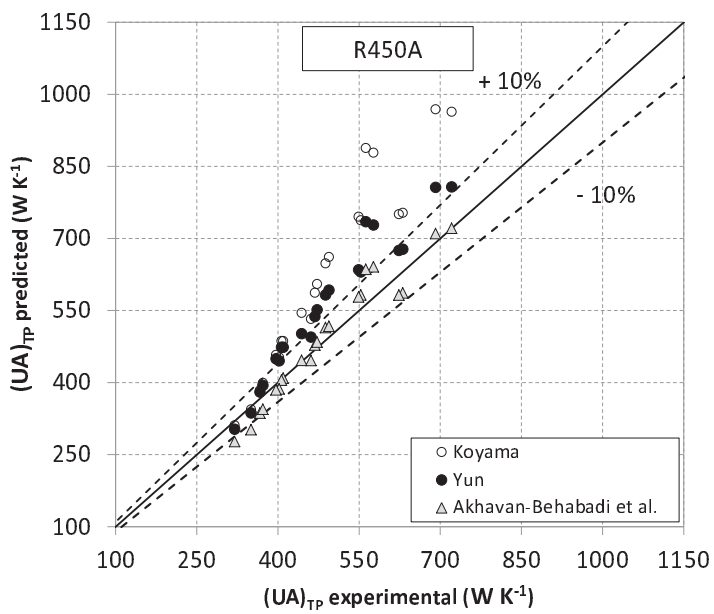

b)

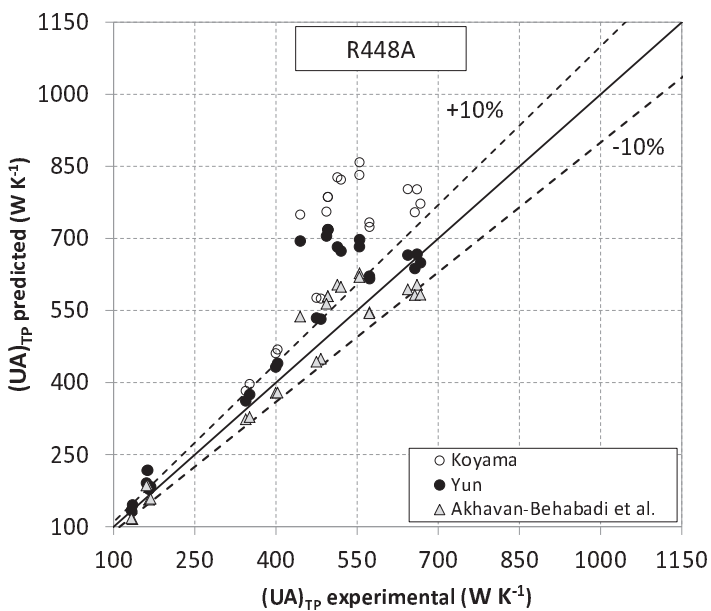

d)

Figure 3. UA $A_{T P}$ model deviations for: a) R134a, b) R450A, c) R404A and d) R448A. 


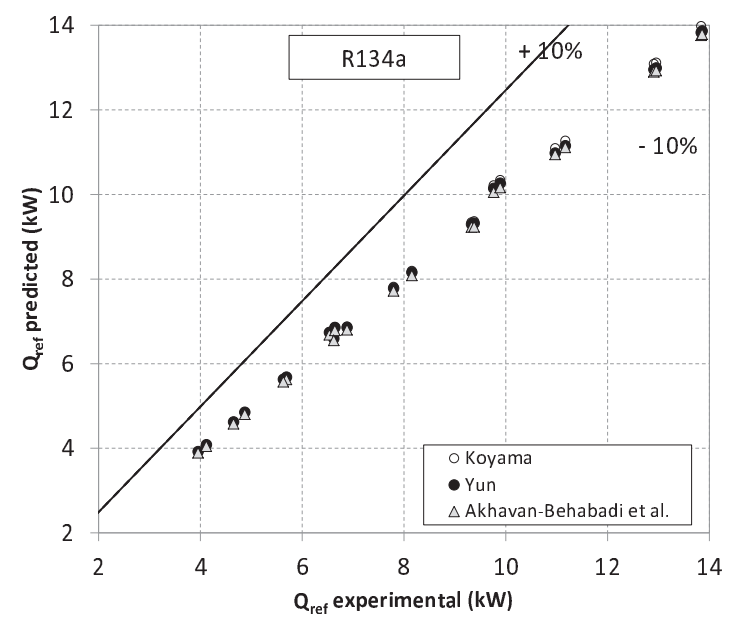

a)

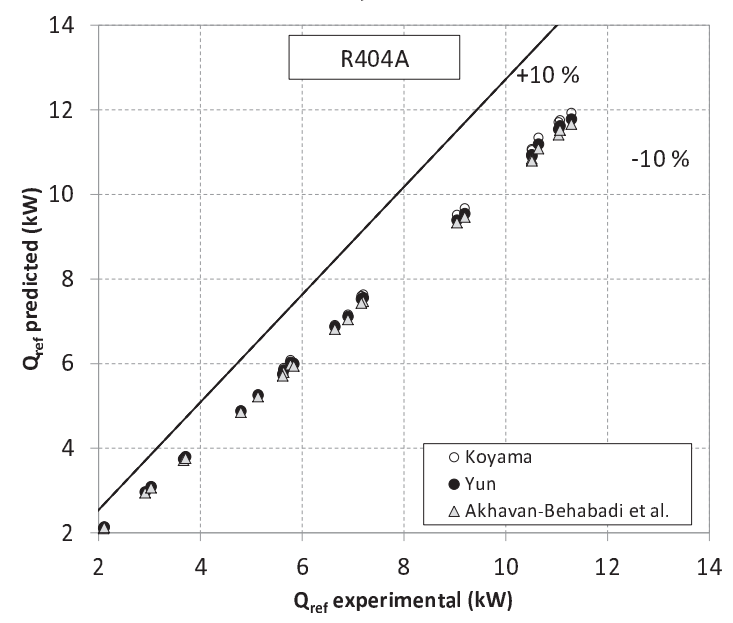

c)

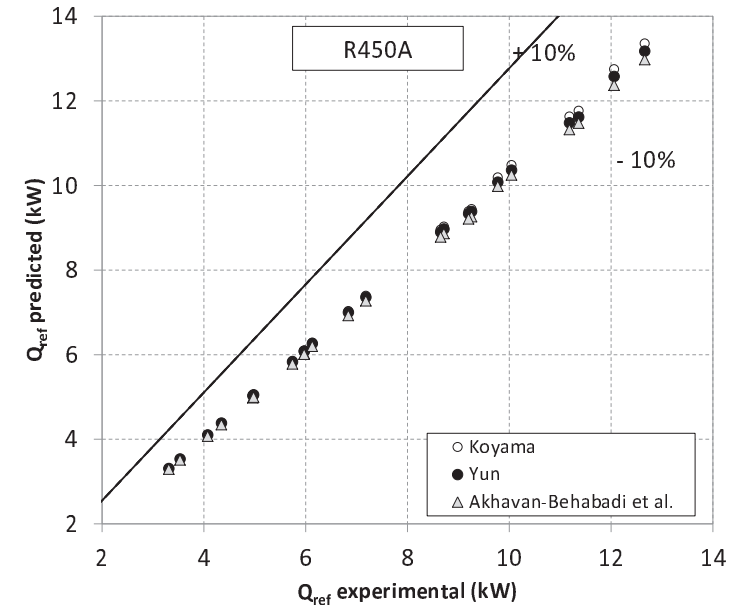

b)

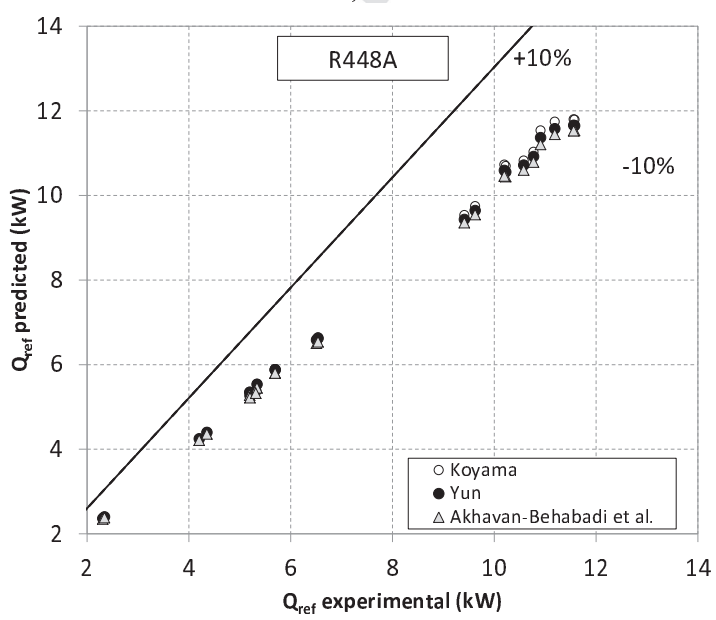

d)

Figure 4. Cooling capacity model deviations for: a) R134a, b) R450A, c) R404A and d) R448A. 


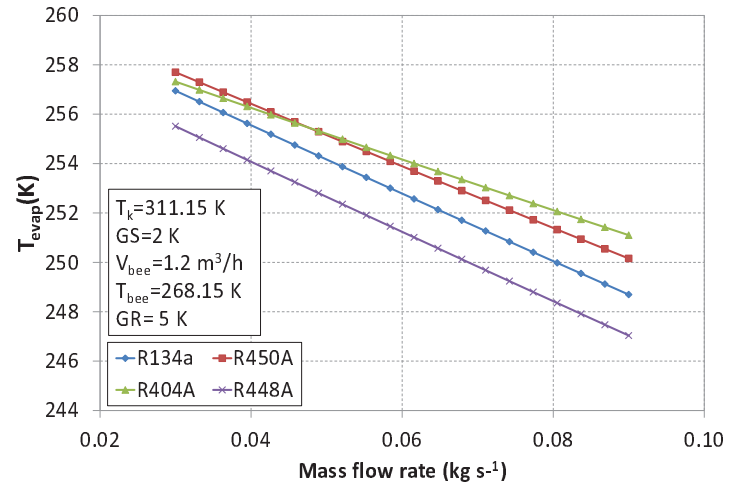

a)

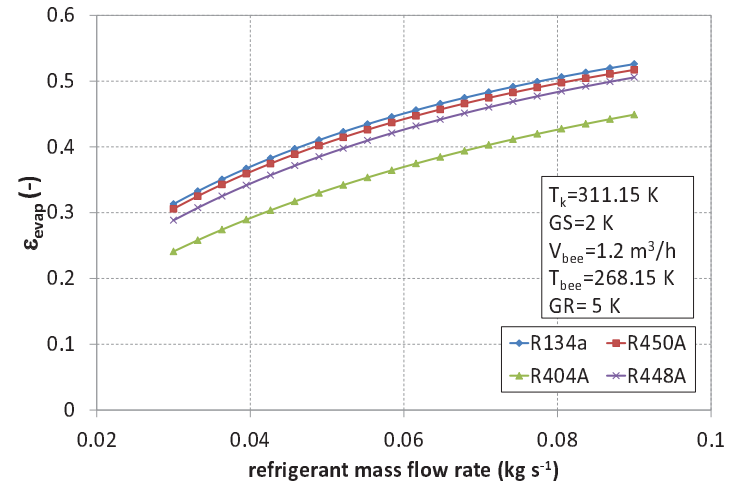

c)

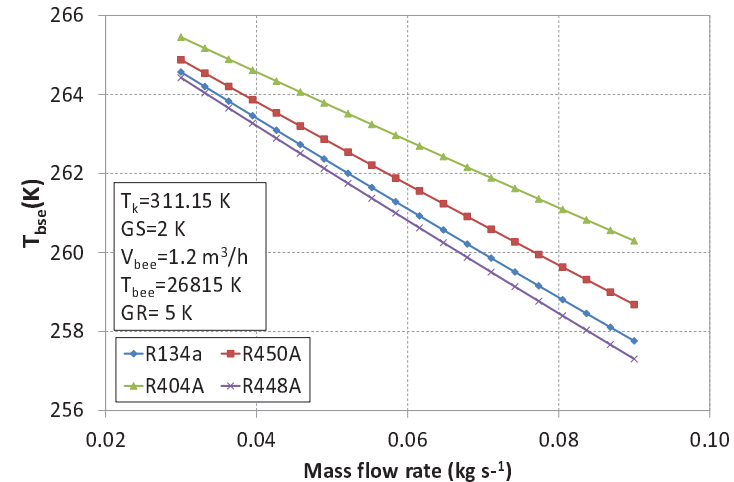

b)

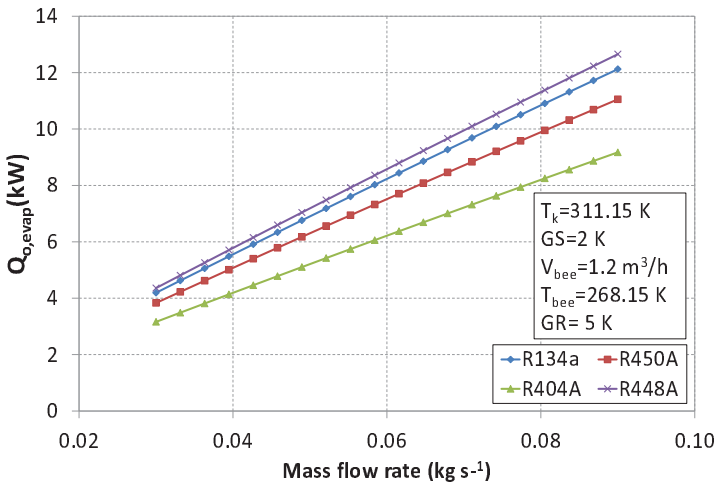

d)

Figure 5. Results of the simulation: a) Evaporating temperature, b) Temperature of the brine at the evaporator outlet, c) Effectiveness at evaporating zone and d) Cooling capacity. 


\section{Figure Captions}

Figure 1. Test bench schematic diagram.

Figure 2. Evaporating pressure model deviations for: a) R134a, b) R450A, c) R404A and d) R448A.

Figure 3. UA $\mathrm{A}_{\mathrm{TP}}$ model deviations for: a) R134a, b) R450A, c) R404A and d) R448A.

Figure 4. Cooling capacity model deviations for: a) R134a, b) R450A, c) R404A and d) R448A.

Figure 5. Results of the simulation: a) Evaporating temperature, b) Temperature of the brine at the evaporator outlet, c) Effectiveness at evaporating zone and d) Cooling capacity. 
Table 1. Refrigerants main properties [30].

\begin{tabular}{|c|c|c|c|c|}
\hline & $\mathrm{R} 134 \mathrm{a}$ & $\mathrm{R} 450 \mathrm{~A}$ & R404A & $\mathrm{R} 448 \mathrm{~A}$ \\
\hline $\begin{array}{l}\text { ASHRAE safety } \\
\text { classification }\end{array}$ & A1 & A1 & A1 & A1 \\
\hline ODP & 0 & 0 & 0 & 0 \\
\hline 100-year GWP & 1430 & 547 & 3922 & 1273 \\
\hline Critical Temperature (K) & 374.21 & 379.02 & 345.20 & 356.81 \\
\hline Critical Pressure (kPa) & 4059.28 & 3814 & 3728.85 & 4674.93 \\
\hline NBP $(K)$ & 247.08 & 521.20 & 227.41 & 233.05 \\
\hline Glide $^{\mathrm{a}}(\mathrm{K})$ & - & 0.78 & 0.75 & 6.27 \\
\hline Liquid density ${ }^{\mathrm{a}}\left(\mathrm{kg} \mathrm{m}^{-3}\right)$ & 1295.27 & 1253.28 & 1150.59 & 1192.39 \\
\hline Vapor density ${ }^{\mathrm{a}}\left(\mathrm{kg} \mathrm{m}^{-3}\right)$ & 14.35 & 13.93 & 30.32 & 22.09 \\
\hline Liquid $\boldsymbol{c}_{\boldsymbol{p}}{ }^{\mathrm{a}}\left(\mathrm{kJ} \mathrm{kg}^{-1} \mathrm{~K}^{-1}\right)$ & 1.34 & 1.32 & 1.39 & 1.42 \\
\hline Vapor $\boldsymbol{c}_{\boldsymbol{p}}{ }^{\mathrm{a}}\left(\mathrm{kJ} \mathrm{kg}^{-1} \mathrm{~K}^{-1}\right)$ & 0.90 & 0.89 & 1.00 & 0.98 \\
\hline $\begin{array}{l}\text { Liquid therm. cond. }{ }^{\mathrm{a}} \text { (W } \\
\mathrm{m}^{-1} \mathrm{~K}^{-1} \text { ) }\end{array}$ & $92.08 \cdot 10^{-3}$ & $83.09 \cdot 10^{-3}$ & $73.15 \cdot 10^{-3}$ & $92.41 \cdot 10^{-3}$ \\
\hline $\begin{array}{l}\text { Vapor therm. cond. }{ }^{\mathrm{a}} \text { (W } \\
\mathrm{m}^{-1} \mathrm{~K}^{-1} \text { ) }\end{array}$ & $11.50 \cdot 10^{-3}$ & $11.57 \cdot 10^{-3}$ & $12.82 \cdot 10^{-3}$ & $12.01 \cdot 10^{-3}$ \\
\hline Liquid viscosity ${ }^{\mathrm{a}}\left(\mathrm{Pa} \mathrm{s}^{-1}\right)$ & $267.04 \cdot 10^{-6}$ & $258.22 \cdot 10^{-6}$ & $179.70 \cdot 10^{-6}$ & $188.35 \cdot 10^{-6}$ \\
\hline Vapor viscosity $^{\mathrm{a}}\left(\mathrm{Pa} \mathrm{s}^{-1}\right)$ & $10.72 \cdot 10^{-6}$ & $11.15 \cdot 10^{-6}$ & $11.00 \cdot 10^{-6}$ & $11.42 \cdot 10^{-6}$ \\
\hline
\end{tabular}


Table 2. Evaporator geometry.

Total number of tubes

76

Number of tube passes

2

Number of Shell passes

1

Inner tube diameter (m)

0.00822

Outside tube diameter (m)

0.00952

Number of micro-fins

30

Fin height (m)

$2 \cdot 10^{-4}$

Helix angle $\left(^{\circ}\right)$ 18

Inner Shell diameter $(\mathrm{m})$

0.131

Tube length (m)

0.8182

Transverse tube spacing (m)

0.01142

Clearance between tubes $(\mathrm{m})$

0.0019

Number of baffles

5

Tube material

Copper 
Table 3. Summary of sensors and their uncertainty associated.

\begin{tabular}{lll}
\hline Measured parameters & Sensor installed & Uncertainty \\
\hline Temperatures & K-type thermocouples & $\pm 0.3 \mathrm{~K}$ \\
Pressures & Piezoelectric pressure transducers & $\pm 7 \mathrm{kPa}$ \\
Mass flow rate & Coriolis mass flow meter & $\pm 0.22 \%$ \\
Volumetric flow rate & Electromagnetic flow meter & $\pm 0.25 \%$ \\
Compressor power consumption & Digital wattmeter & $\pm 0.15 \%$ \\
Compressor rotation speed & Capacitive sensor & $\pm 1 \%$ \\
\hline
\end{tabular}


Table 4. Test conditions (min-max)

\begin{tabular}{|c|c|c|c|c|}
\hline & R134a & R450A & R404A & R448A \\
\hline Evaporation pressure $(\mathrm{kPa})$ & $175.8-375.2$ & $163.9-350.9$ & $162.6-418.3$ & $132.5-401.2$ \\
\hline $\begin{array}{l}\text { Refrigerant mass flow rate } \\
\left(\mathrm{kg} \mathrm{s}^{-1}\right)\end{array}$ & $0.031-0.086$ & $0.029-0.085$ & $\begin{array}{l}0.021- \\
0.096\end{array}$ & $0.009-0.075$ \\
\hline $\begin{array}{l}\text { Refrigerant quality at } \\
\text { evaporator inlet }\end{array}$ & $0.19-0.43$ & $0.21-0.47$ & $0.25-0.58$ & $0.23-0.46$ \\
\hline $\begin{array}{l}\text { Refrigerant superheat at } \\
\text { evaporator exit }(\mathrm{K})\end{array}$ & $5.6-9.8$ & $6.5-10.2$ & $5.5-13.5$ & $9.7-11.8$ \\
\hline $\begin{array}{l}\text { Brine propylene glycol } \\
\text { inlet temperature }(\mathrm{K})\end{array}$ & $264.8-293.4$ & $270.2-305.0$ & 250.3290 .9 & $\begin{array}{l}250.43- \\
287.88\end{array}$ \\
\hline $\begin{array}{l}\text { Brine propylene glycol } \\
\text { outlet temperature }(\mathrm{K})\end{array}$ & 263.9-290.6 & $268.5-296.3$ & $248.3-285.0$ & $\begin{array}{l}248.98- \\
287.25\end{array}$ \\
\hline $\begin{array}{l}\text { Secondary fluid volumetric } \\
\text { flow rate }\left(\mathrm{m}^{-1} \mathrm{~h}^{-1}\right)\end{array}$ & $1.14-1.24$ & $1.17-1.27$ & $1.02-1.82$ & $1.09-1.83$ \\
\hline
\end{tabular}


Table 5. Equations used in the Koyama et al. correlation [38].

$$
\begin{aligned}
& \alpha_{T P}=\alpha_{n b}+\alpha_{c b} \\
& \alpha_{c b}=0.028 F^{1 / 0.8} \mathrm{Re}_{l}^{0.8} \operatorname{Pr}_{l}^{0.4}\left(\frac{k_{l}}{d_{i}}\right) \\
& \mathrm{Re}_{l}=\frac{G(1-x) d_{i}}{\mu_{l}} \\
& F=1+2\left(\frac{1}{X_{t t}}\right)^{-0.88}+0.8\left(\frac{1}{X_{t t}}\right)^{1.03} \\
& \alpha_{n b}=K^{0.745} S \alpha_{p b} \\
& K^{0.745}=\left(1+0.875 \eta+0.518 \eta^{2}-0.159 \eta^{3}+0.7907 \eta^{4}\right)^{-1} \\
& \eta=\frac{\alpha_{c b}}{S \alpha_{p b}} ; \quad S=\frac{1-\exp (-\xi)}{\xi} ; \quad \xi=\frac{D_{b} \alpha_{c b}}{k_{l}} \\
& D_{b}=1 \times 10^{-5}\left(\frac{\rho_{l} C_{p, l} T_{\text {evap }}}{\rho_{\nu} h_{l v}}\right)^{1.25}\left(\frac{2 \sigma}{g\left(\rho_{l}-\rho_{v}\right)}\right)^{0.5} \\
& \alpha_{p b}=579.6\left(\frac{k_{l}}{D_{b e}}\right)\left(\frac{q^{\prime \prime} D_{b e}}{k_{l} T_{\text {evap }}}\right)^{0.745}\left(\frac{\rho_{l}}{\rho_{v}}\right)^{0.581} \operatorname{Pr}_{l}^{0.533} \\
& D_{b e}=0.51\left(\frac{2 \sigma}{g\left(\rho_{l}-\rho_{v}\right)}\right)^{0.5}
\end{aligned}
$$


Table 6. Coefficients used on the Yun et al. correlation [39].

$\begin{array}{lllllllllll}\text { Coefficient } & C_{1} & C_{2} & C_{3} & C_{4} & C_{5} & C_{6} & C_{7} & C_{8} & C_{9}\end{array}$

Value

$\begin{array}{llllll}0.009622 & 0.1106 & 0.3814 & 7.685 & 0.51 & -0.736\end{array}$

0.2045

0.7452

$-0.1302$ 
Table 7. Statistical analysis of selected parameters of the model and experimental results.

\begin{tabular}{|c|c|c|c|c|c|c|}
\hline Refrigerant & Parameter & Correlation & $\bar{\omega}$ & $|\bar{\omega}|$ & $\theta$ & $\lambda_{10 \%}$ \\
\hline \multirow[t]{9}{*}{ R134a } & \multirow[t]{3}{*}{$\mathrm{P}_{\text {evap }}$} & Koyama & $5.19 \%$ & $7.43 \%$ & $10.04 \%$ & $82 \%$ \\
\hline & & Yun & $2.05 \%$ & $5.28 \%$ & $8.59 \%$ & $82 \%$ \\
\hline & & Akhavan & $-2.58 \%$ & $7.30 \%$ & $7.61 \%$ & $82 \%$ \\
\hline & \multirow[t]{3}{*}{$\mathrm{UA}_{\mathrm{TP}}$} & Koyama & $34.25 \%$ & $34.53 \%$ & $28.60 \%$ & $18 \%$ \\
\hline & & Yun & $24.41 \%$ & $24.41 \%$ & $23.79 \%$ & $18 \%$ \\
\hline & & Akhavan & $9.89 \%$ & $14.84 \%$ & $21.43 \%$ & $59 \%$ \\
\hline & \multirow{3}{*}{$Q_{o, \text { ref }}$} & Koyama & $0.90 \%$ & $1.25 \%$ & $1.61 \%$ & $100 \%$ \\
\hline & & Yun & $0.56 \%$ & $0.90 \%$ & $1.48 \%$ & $100 \%$ \\
\hline & & Akhavan & $-0.32 \%$ & $1.25 \%$ & $1.44 \%$ & $100 \%$ \\
\hline \multirow[t]{9}{*}{$\mathrm{R} 450 \mathrm{~A}$} & \multirow[t]{3}{*}{$\mathrm{P}_{\text {evap }}$} & Koyama & $13.20 \%$ & $13.20 \%$ & $6.96 \%$ & $32 \%$ \\
\hline & & Yun & $8.98 \%$ & $8.98 \%$ & $4.35 \%$ & $59 \%$ \\
\hline & & Akhavan & $2.98 \%$ & $3.74 \%$ & $3.62 \%$ & $91 \%$ \\
\hline & \multirow[t]{3}{*}{$\mathrm{UA}_{\mathrm{TP}}$} & Koyama & $23.88 \%$ & $24.29 \%$ & $15.26 \%$ & $18 \%$ \\
\hline & & Yun & $12.67 \%$ & $13.51 \%$ & $8.21 \%$ & $32 \%$ \\
\hline & & Akhavan & $-0.64 \%$ & $5.45 \%$ & $6.85 \%$ & $82 \%$ \\
\hline & \multirow{3}{*}{$\mathrm{Q}_{\mathrm{o}, \mathrm{ref}}$} & Koyama & $2.59 \%$ & $2.60 \%$ & $1.57 \%$ & $100 \%$ \\
\hline & & Yun & $2.04 \%$ & $2.04 \%$ & $1.12 \%$ & $100 \%$ \\
\hline & & Akhavan & $0.93 \%$ & $1.03 \%$ & $0.90 \%$ & $100 \%$ \\
\hline \multirow[t]{9}{*}{ R404A } & \multirow[t]{3}{*}{$\mathrm{P}_{\text {evap }}$} & Koyama & $18.25 \%$ & $18.25 \%$ & $7.72 \%$ & $17 \%$ \\
\hline & & Yun & $11.83 \%$ & $11.83 \%$ & $4.26 \%$ & $33 \%$ \\
\hline & & Akhavan & $7.70 \%$ & $7.71 \%$ & $3.95 \%$ & $67 \%$ \\
\hline & \multirow[t]{3}{*}{$\mathrm{UA}_{\mathrm{TP}}$} & Koyama & $31.30 \%$ & $31.30 \%$ & $13.68 \%$ & $4 \%$ \\
\hline & & Yun & $15.78 \%$ & $15.82 \%$ & $9.32 \%$ & $25 \%$ \\
\hline & & Akhavan & $6.25 \%$ & $7.53 \%$ & $7.30 \%$ & $79 \%$ \\
\hline & \multirow[t]{3}{*}{$Q_{o, \text { ref }}$} & Koyama & $4.02 \%$ & $4.02 \%$ & $1.78 \%$ & $100 \%$ \\
\hline & & Yun & $3.28 \%$ & $3.28 \%$ & $1.31 \%$ & $100 \%$ \\
\hline & & Akhavan & 2.41 & $2.41 \%$ & $1.13 \%$ & $100 \%$ \\
\hline \multirow[t]{9}{*}{ R448A } & \multirow[t]{3}{*}{$\mathrm{P}_{\text {evap }}$} & Koyama & $14.35 \%$ & $14.35 \%$ & $7.59 \%$ & $62 \%$ \\
\hline & & Yun & $9.42 \%$ & $9.42 \%$ & $5.49 \%$ & $62 \%$ \\
\hline & & Akhavan & $2.68 \%$ & $4.33 \%$ & $5.35 \%$ & $85 \%$ \\
\hline & \multirow{6}{*}{$\begin{array}{l}\mathrm{UA}_{\mathrm{TP}} \\
\mathrm{Q}_{\mathrm{o}, \mathrm{ref}}\end{array}$} & Koyama & $29.71 \%$ & $29.96 \%$ & $20.69 \%$ & $54 \%$ \\
\hline & & Yun & $17.04 \%$ & $17.47 \%$ & $16.31 \%$ & $54 \%$ \\
\hline & & Akhavan & $1.18 \%$ & $10.89 \%$ & $11.80 \%$ & $46 \%$ \\
\hline & & Koyama & $2.27 \%$ & $2.31 \%$ & $1.59 \%$ & $100 \%$ \\
\hline & & Yun & $1.76 \%$ & $1.76 \%$ & $1.27 \%$ & $100 \%$ \\
\hline & & Akhavan & $0.731 \%$ & $0.96 \%$ & $1.10 \%$ & $100 \%$ \\
\hline
\end{tabular}

